\title{
Development of Audio Visual Health Education Media About Self Management in Patients Type II Diabetes Mellitus
}

\author{
Rifa Ainun Najihah ${ }^{1}$, Nina Indriyawati², Mugi Hartoyo ${ }^{2}$ \\ ${ }^{1}$ Program Studi Sarjana Terapan Keperawatan, Jurusan Keperawatan, Poltekkes KemenkesSemarang \\ ${ }^{2}$ Jurusan Keperawatan, Poltekkes Kemenkes Semarang \\ Corresponding author: Rifaainun3098@gmail.com
}

\begin{abstract}
Background: Self-management in patients with diabetes mellitus (DM) type II aims to control blood sugar levels and prevent the occurrence of disease complications. The media must be able to help understand information. One of the media that can be used is audiovisual that can stimulate vision and hearing senses. Audio Visual Media comes with images, background songs, sounds, and colors so it can cause interest.

Purpose: Developing audiovisual about self-management in type II Diabetes Mellitus patients.

Methods: This research used R\&D (research and development) methods with the ADDIE model. This research was only done through the process from analysis, design, and development process with 3 expert validation testing and 10 limited trials. The Analysis of data used is quantitative descriptive with a Likert scale of the value range of 1-5 and qualitative descriptive in the form of comments, suggestions, and criticisms. Results: the results of this study had developed 2 audiovisual videos using Indonesian. Average audiovisual media assessment results from 3 experts and 10 limited trials got categories worth using.

Conclusion: Audiovisual media presents general knowledge material about diabetes mellitus and self-management in type 2 diabetes mellitus patients and is equipped with animated images, backsound music and dubbing material. Audiovisual about self-management in type II diabetes mellitus iscategorized as suitable for use.
\end{abstract}

Keywords:

Audiovisual; Diabetes Mellitus; health education; media development; self management.

\section{LATAR BELAKANG}

Penyakit diabetes melitus (DM) menjadi salah satu masalah kesehatan masyarakat yang dapat berpengaruh pada morbiditas dan mortalitas penderita diabetes melitus. Menurut Riset Kesehatan Dasar tahun 2018 prevalensi penyakit DM mengalami peningkatan dari tahun 2013 - 2018 yaitu dari jumlah 6,9\% menjadi 8,5\% atau setara dengan 16 juta penderita DM (Kementerian Kesehatan RI, 2018). Prevalensi DM tipe 2 lebih tinggi dari DM tipe 1 dengan jumlah kasus yaitu $90 \%$ (International Diabetes

For complete information author guidelines please check 
Federation [IDF], 2017). Penyebab DM tipe 2 yaitu obesitas, pola makan dan nutrisi yang buruk, kurang aktivitas fisik, toleransi glukosa yang terganggu (TGT), merokok dan riwayat DM gestasional (IDF, 2017).

Upaya pengendalian penyakit DM dapat dilakukan dengan pengaturan pola makan yang sehat, aktivitas fisik, terapi farmakologis dan pendidikan kesehatan (Perkumpulan Endokrinologi Indonesia [PERKENI], 2015). Informasi yang dibutuhkan pada penderita DM melalui pendidikan kesehatan bertujuan untuk meningkatkan manajemen diri (self management) (Hestiana, 2017). Manajemen diri pada DM bertujuan untuk mengontrol kadar gula darah dan mencegah terjadinya komplikasi penyakit yang mengharuskan perubahan gaya hidup dengan mengontrol gula darah, obat-obatan, kadar gula dalam makanan dan minuman, perawatan kaki dan kulit serta olahraga yang teratur (Mulyani, 2016).

Berdasarkan hasil penelitian Hidayah, (2019) gambaran tingkat self management pada klien dengan DM masih kurang pada beberapa aspek antara lain aktivitas fisik/olahraga, perawatan kaki dan monitoring glukosa. Dukungan manajemen diri diabetes diperlukan untuk menerapkan, mempertahankan keterampilan serta perilaku koping yang berkelanjutan. Manajemen diri diabetes dipengaruhi oleh beberapa faktor antara lain kepercayaan kesehatan, dukungan keluarga, status keuangan, kesadaran pentingnya kesehatan dan pengetahuan (Powers et al., 2015). Berdasarkan hasil penelitian Anggraini, Hariyanto dan Warsono (2018) menunjukkan bahwa terdapat perbedaan tingkat pengetahuan tentang DM sebelum dan sesudah menggunakan media audio visual pada klien DM tipe II $(p=0,000)$ atau $\alpha<0,005$.

Berdasarkan hasil penelitian dan wawancara tidak terstruktur mengenai penggunaan media pendidikan kesehatan dibeberapa rumah sakit didapatkan hasil antara lain : Media promosi kesehatan yang digunakan di RSUD Tugurejo Provinsi Jawa Tengah menggunakan media cetak antara lain : media poster yang ditempatkan pada beberapa lokasi strategis dan media cetak yang berisikan tentang praktik cuci tangan sebelum dan sesudah mengnjungi pasien (Husodo \& Canti, 2016). Hasil penelitian di Poliklinik RSUP dr Kariadi menunjukkan bahwa media pendidikan kesehatan yang digunakan perawat yaitu media lembar balik dan media leaflet (Rosymida, Adi, \& Aisah, 2018). Adapun hasil wawancara kepada salah satu perawat di RSUD K.R.M.T Wongsonegoro mengatakan bahwa media pendidikan kesehatan yang digunakan antara lain : leaflet, lembar balik dan power point (Wahyu, 2020). Serta RSU Roemani Muhamadiyah Semarang masih menggunakan media leaflet, lembar balik dan PPT, serta belum ada pendidikan kesehatan yang menggunakan media audio visual (Bekti, 2019). Berdasarkan hasil-hasil penelitian, wawancara dan studi pendahuluan diatas mengenai media pendidikan kesehatan belum menggunakan media berbasis video audio visual mengenai self management pada DM tipe 2 maka peneliti tertarik mengembangkan media audio visual. Media yang dikembangkan menyajikan materi mengenai pengetahuan umum tentang diabetes mellitus dan self management pada pasien diabetes mellitus tipe 2. Media audio visual dilengkapi dengan gambar animasi, backsound musik dan pengisi suara materi (dubbing).

\section{TUJUAN}

Tujuan umum pada penelitian ini yaitu untuk mengetahui bagaimana mengembangkan

For complete information author guidelines please check 
media pendidikan kesehatan audio visual tentang self management pada pasien DM tipe II.

\section{METODE}

Desain penelitian ini menggunakan metode penelitian pengembangan atau $R$ \& $D$ (research and development) dengan menggunakan metode model ADDIE sampai pada tahap analisis kebutuhan (analysis), perancangan konsep (design) dan pengembangan (development) (Jatmika, dkk, 2019). Penelitian ini telah melalui ijin etik dengan No.TP-007/KEPK-RSR/11/2020 yang dikeluarkan oleh RSU Roemani Muhammadiyah Semarang dan dilaksanakan pada bulan 5 Februari - 7 Maret 2020 di RSU Roemani Muhammadiyah Semarang. Subyek dalam penelitian ini terdapat 3 ahli yaitu ahli promosi kesehatan, ahli praktisi keperawatan dan ahli keperawatan medikal bedah serta dilakukan uji lapangan terbatas pada 10 responden yang memiliki penyakit diabetes melitus tipe 2 di RSU Roemani Muhamadiyah Semarang.

Pengumpulan data mengenai media audio visual tentang self management dilakukan dengan memberikan lembar validasi ahli yang meliputi 3 aspek penilaian antara lain : aspek materi, aspek isi dan aspek tampilan. Lembar Angket Responden meliputi 3 aspek penilaian antara lain : aspek materi, pemahaman dan tampilan. Angket penilaian yang diberikan kepada ahli dan responden menggunakan skala likert yang mempunyai skor 1 sampai dengan 5, dimana nanti ahli akan memberikan tanda ceklis ( $\square$ ) untuk jawaban yang dipilih sesuai dengan pernyataan yang ada pada angket. Setelah media audio visual mendapatkan skor penilaian oleh para ahli dan uji lapangan terbatas dari lembar validasi selanjutnya untuk menentukan nilai presentase kelayakan maka dimasukkan ke dalam rumus:

$$
\begin{aligned}
& \text { Sumber : (Suharsimi Arikunto dalam Endryany (2018) } \\
& \text { nilai akhir }=\frac{\text { jumlah skor yang diperoleh }}{\text { jumlah skor maksimal }} \times 100 \%
\end{aligned}
$$

Apabila nilai telah diperoleh, maka untuk mengetahui kategori kelayakan media audiovisual mengenai self management untuk pasien DM tipe 2 dapat dilihat berdasarkanempat kategori yaitu :

Tabel 1. Kategori kelayakan

\begin{tabular}{cc}
\hline Nilai & Kategori \\
\hline $0 \%-25 \%$ & Tidak layak \\
$26 \%-50 \%$ & Layak dengan revisi \\
& besar \\
$51 \%-75 \%$ & Layak dengan Revisi \\
$76 \%-100 \%$ & Kecil \\
& Sangat layak \\
\hline
\end{tabular}

Sumber : Suharsimi Arikunto (dalam Endryany, 2018) 


\section{HASIL}

a. Tahap Analisis (analysis)

Pada tahap ini peneliti melakukan studi literature, studi pendahuluan dan wawancara tidak terstruktur di beberapa rumah sakit di Semarang. Adapun hasil studi pendahuluan yang telah dilakukan dengan wawancara tidak terstruktur kepada kepala bagian keperawatan RSU Roemani Muhammadiyah Semarang didapatkan hasil bahwa pada media pendidikan kesehatan yang telah dilakukan yaitu menggunakan media cetak berupa leaflet, lembar balik dan power point (PPT) serta belum ada pendidikan kesehatan menggunakan media audio visual. Kemudian penggunaan media pendidikan kesehatan dibeberapa rumah sakit didapatkan hasil antara lain : Media promosi kesehatan yang digunakan di RSUD Tugurejo Provinsi Jawa Tengah menggunakan media cetak antara lain : media poster yang ditempatkan pada beberapa lokasi strategis dan media cetak yang berisikan tentang praktik cuci tangan sebelum dan sesudah mengnjungi pasien (Husodo \& Canti, 2016). Hasil penelitian di Poliklinik RSUP dr Kariadi menunjukkan bahwa media pendidikan kesehatan yang digunakan perawat yaitu media lembar balik dan media leaflet (Rosymida et al., 2018). Adapun hasil wawancara kepada salah satu perawat di RSUD K.R.M.T Wongsonegoro mengatakan bahwa media pendidikan kesehatan yang digunakan antara lain : leaflet, lembar balik dan power point (Wahyu, 2020).

Media digunakan sebagai sarana untuk memberikan informasi sesuai dengan kebutuhan pasien, adapun informasi yang dibutuhkan pada penderita DM melalui pendidikan kesehatan bertujuan untuk meningkatkan manajemen diri (selfmanagement) (Hestiana, 2017). Manajemen diri pada pasien DM bertujuan untuk mengontrol kadar gula darah dan mencegah terjadinya komplikasi penyakit, mengontrol gula darah, obatobatan, kadar gula dalam makanan dan minuman, perawatan kaki dan kulit serta olahraga yang teratur (Mulyani, 2016). Kemudian media audio visual dapat meningkatkan pengetahuan berdasarkan hasil penelitian Anggraini, Hariyanto dan Warsono (2018) menunjukkan bahwa terdapat perbedaan tingkat pengetahuan tentang DM sebelum dan sesudah menggunakan media audio visual pada klien DM tipe II $(\mathrm{p}=0,000)$ atau $\alpha<0,005$. Media audio visualmerupakan media yang dapat membantu menstimulasi indra penglihatan danpendengaran pada saat terjadinya penerimaan pesan (Jatmika, dkk 2019).

\section{b. Perancangan Konsep (Design)}

Pada tahap perancangan konsep dilakukan dengan penyusunan naskah media audio visual meliputi pengetahuan umum penyakit DM dan self management pada DM tipe 2 . Kemudian melakukan rancangan pembuatan media audio visual menggunakan adobe photoshop dan aplikasi adobe after effect.

\section{c. Pengembangan Model (Development)}

1) Pengembangan Desain Awal Media

Pembuatan media audio visual menggunakan aplikasi adobe after effect. Video ditampilkan menjadi 2 sesi, pada sesi pertama mengenai pengetahuan umum penyakit DM dengan durasi 3:55 menit, sedangkan pada sesi kedua mengenaiself management pada pasien DM tipe 2 meliputi : monitor kadar gula darah, mengatur konsumsi makanan, mengatur penggunaan obat-obatan, mengatur aktivitas fisik dan perawatan kaki dengan durasi 7:37 menit. Media audio visual dilengkapi dengan gambar animasi, penyajian For complete information author guidelines please check 
materi singkat, backsound video dan pengisian suara (dubbing).

2) Validasi Ahli dan Uji Lapangan terbatas

Pada penelitian ini terdapat 3 ahli yaitu dosen promosi kesehatan, dosen keperawatan medikal bedan Poltekkes Kemenkes Semarang dan praktisi keperawaran ruang penyakit dalam RSU Roemani Muhammadiyah Semarang. Dari penilaian yang diberikan oleh 3 ahli pada aspek materi, aspek isi dan aspek tampilan mendapat kategori sangat layak. hasil uji lapangan terbatas yang dilakukan oleh 10 responden mendapatkan kategori sangat layak pada semua aspek yaitu aspek materi, aspek pemahaman dan aspek tampilan.

3) Penilaian kelayakan Media Audio Visual

Penilaian kelayakan media audio visual dilakukan oleh 3 ahli dan 10 responden. berikut adalah rata-rata persentase penilaian kelayakan media audio visual :

Tabel 2. Rata-rata persentase ahli

\begin{tabular}{cc}
\hline Aspek Penilaian & Persentase \\
\hline materi & $93 \%$ (sangat layak) \\
Isi & $90 \%$ (sangat layak) \\
Tampilan & $97 \%$ (sangat layak) \\
\hline
\end{tabular}

Berdasarkan hasil rata-rata persentase penilaian medi audio visual oleh 3 ahli didapatkan hasil pada aspek materi 93\% dengan kategori sangat layak, aspek isi 90\% dengan kategori sangat layak dan aspek tampilan 97\% dengan kategori sangat layak.

Tabel 3. Rata-rata persentase uji coba terbatas

\begin{tabular}{cc}
\hline Aspek Penilaian & Persentase \\
\hline materi & $96.5 \%$ (sangat layak) \\
Pemahaman & $93 \%$ (sangat layak) \\
Tampilan & $97 \%$ (sangat layak) \\
\hline
\end{tabular}

Berdasarkan hasil uji coba terbatas media audio visual pada pasien DM tipe II didapatkan hasil bahwa persentase pada aspek materi didapatkan hasil $96.5 \%$ dengan kategori sangat layak, aspek pemahaman $93 \%$ dengan kategori sangat layak dan aspek tampilan $97 \%$ dengan kategori sangat layak.

\section{PEMBAHASAN}

Pengembangan media audio visual mengenai self management pada pasien diabetes mellitus tipe 2 dilakukan melalui 3 tahap antara lain : analisis (analysis), perancangan konsep (design) dan pengembangan (development). Media audio visual ditampilkan menjadi 2 sesi yaitu pada video sesi pertama mengenai pengetahuan umum penyakit DM dan sesi kedua mengenai self

management pada DM tipe 2. Pembuatan media audio visual menggunakan aplikasi adobe after effect. Pada penelitian Mawan, 
Indriawati dan Suhadi (2017) mengenai pengembangan video penyuluhan tentang perilaku hidup bersih dan sehat (PHBS) menggunakan software adobe after effect. Pada Software adobe after effect juga digunakan pada penelitian mengenai media edukasi penyimpangan perilaku seksual pada remaja yang dibuat dalam bentuk animasi (Aprianto, 2019). Software adobe after effect biasa digunakan untuk kebutuhan motion graphic design, memiliki standar efek yang mencapai 50 jenis serta dapat merubah dan menganimasikan obyek (Supriyadi, 2019).

Media audio visual telah dilakukan uji validitas oleh 3 ahli meliputi 3 aspek yaitu aspek materi, aspek isi dan aspek tampilan. Berdasarkan hasil rata-rata persentase penilaian medi audio visual oleh 3 ahli didapatkan hasil pada aspek materi 93\% dengan kategori sangat layak, aspek isi $90 \%$ dengan kategori sangat layak dan aspek tampilan 97\% dengan kategori sangat layak. Berbeda dengan penelitian sebelumnya yang melakukan uji validitas pada 2 ahli yaitu ahli media dan ahli materi, hasil validitas dari ahli media yaitu $97.3 \%$ dengan kategori sangat layak tanpa revisi dan hasil validitas dari ahli materi yaitu 80\% dengan kategori sangat layak tanpa revisi (Hayatun \& Jatmika, 2019). Sedangkan jumlah ahli pada penelitian ini sama dengan penelitian Prasetiyo dan Perwiraningtyas (2017) yaitu mengujikan produk pada 3 ahli antara lain : validator ahli materi, validator ahli bahasa, dan validator ahli media. Uji ahli bertujuan untuk mengetahui kelayakan pada media yang dikembangkan.

Setelah dilakukan uji validitas oleh ahli maka media audio visual mengenai self management dilakukan uji lapangan terbatas kepada 10 responden yang memiliki penyakit diabetes melitus tipe II di RSU Roemani Muhammadiyah Semarang. Dari penilaian hasil uji lapangan terbatas mengenai aspek tampilan mendapatkan rata-rata persentase tertinggi yaitu 97\% dengan kategori sangat layak. Tampilan yang dihasilkan melalui media audio visual dilengkapi oleh gambar animasi, backsound lagu, suara dan pemilihan warna sehingga media audio visual merupakan media yang dapat menimbulkan minat dan ketertarikan (Sanjaya, 2011). (Sanjaya, 2011). Kemudian menurut Jatmika, dkk (2019) media yang telah dilakukan uji secara internal oleh ahli selanjutnya media dilakukan uji lapangan terbatas menggunakan 6-12 subjek. Hal tersebut sama dengan jumlah responden pada pengembangan media pendidikan kesehatan untuk uji lapangan terbatas yaitu 10 responden. Berbeda dengan penelitian (Lianto, Jufri, \& Merta, 2018).

Pada hasil penelitian pengembangan kelayakan media audio visual mengenai self management pada pasien DM tipe 2 yang didapatkan dari uji validitas oleh 3 ahli dan uji coba lapangan terbatas pada 10 responden mendapatkan kategori sangat layak pada semua aspek penilaian. Hal tersebut sama dengan penelitian mengenai pengembangan media pembelajaran berbasis audio visual mendapatkan hasil uji validitas ahli dengan nilai rata-rata 86,43\% dengan kategori sangat layak digunakan (Pradilasari, Gani, \& Khaldun, 2019).

Kekurangan pada media audio visual yang telah dikembangkan yaitu metode pendidikan kesehatan dengan media audio visual menjadi satu arah atau tidak ada timbal balik sehingga informasi yang disampaikan hanya terbatas pada materi yang ada pada media. Pengembangan media audio visual menggunakan model pengembangan analisis For complete information author guidelines please check 
(anlysis), perancangan konsep (design), pengembangan (development), implementasi (implementation) dan evaluasi (evaluation) ADDIE hanya sampai pada tahap pengembangan (development) belum sampai pada tahap evaluasi. Sehingga diperlukan pengembangan media pendidikan kesehatan berbasis audio visual sampai pada tahap evaluasi untuk mengetahui keefektifan media.

\section{SIMPULAN}

Media audio visual yang telah dikembangkan ditampilkan dalam bentuk video audio visual menjadi 2 sesi. Pada sesi pertama mengenai pengetahuan umum penyakit DM dengan durasi 3:55 menit dan pada sesi kedua mengenai self management pada DM tipe 2 dengan durasi waktu 7:37 menit. Hasil penilaian kelayakan media audio visual oleh 3 ahli dan uji lapangan terbatas mendapatkan hasil media sangat layak digunakan. Bagi peneliti selanjutnya untuk pengembangan media audio visual mengenai self management pada pasien DM tipe II dapat dikembangkan dengan menambahkan materi sesuai dengan keinginan dari penderita DM, fokus pada materi self management dan dilanjutkan dengan uji coba lapangan dengan sampel yang lebih luas untuk menguji keefektifan media.

\section{REFERENSI}

Anggraini, N. R. F., Hariyanto, T., \& Warsono. (2018). Perbedaan Tingkat Pengetahuan tentang Diabetes Mellitus (DM) Tipe II Sebelum dan Sesudah Diberikan Edukasi Dengan Media Audio Visual Pada Penderita Diabetes Mellitus Tipe II di Dusun Sentong Desa Karangduren Kecamatan Pakisaji Kabupaten Malang. Jurnal Ilmiah Keperawatan, 3.

Hestiana, D. W. (2017). Faktor-Faktor Yang Berhubungan Dengan Kepatuhan Dalam Pengelolaan Diet Pada Pasien Rawat Jalan Diabetes Mellitus Tipe 2 Di Kota Semarang. Journal of Health Education, 2(2), 137-145. https://doi.org/10.15294/jhe.v2i2.14448

Hidayah, M. (2019). Hubungan Perilaku Self-Management Dengan Kadar Gula Darah Pada Pasien Diabetes Mellitus Tipe 2 Di Wilayah Kerja Puskesmas Pucang Sewu, Surabaya The Relationship between Self-Management Behaviour and Blood Glucose Level in Diabetes Mellitus Type 2 Patient. 176-182. https://doi.org/10.2473/amnt.v3i3.2019.176-182

Husodo, B. T., \& Canti, P. R. (2016). Paparan Media Promosi Kesehatan Dengan Pengetahuan Pencegahan Infeksi Bagi Pengunjung Rumah Sakit. Jurnal Ilmiah Komunikasi, 6(2).

Jatmika, S. E. D., Maulana, M., Kuntoro, \& Martini, S. (2019). Buku Ajar Pengembangan Media Promosi Kesehatan (E. Khuzzaimah, ed.). Yogyakarta: K-Media. 
Mawan, A. R., Indriawati, S. E., \& Suhadi. (2017). Pengembangan Video Penyuluhan PHBS Bermuatan Nilai Karakter terhadap Peningkatan Pengetahuan Masyarakat dalam Menanggulangi Diare. Pendidikan, 2, 883-888. Retrieved from journal.um.ac.id/index.php/jptpp/article/view/9606

Mulyani, N. S. (2016). Hubungan Self Management Pasien Diabetes. Jurnal Kesehatan Masyarakat, 3(2), 56-63. https://doi.org/10.1192/bjp.bp.111.104257

Perkumpulan Endokrinologi Indonesia [PERKENI]. (2015). Konsnsus Pengelolaan dan Pencegahan Diabetes Melitus Tipe 2 di Indonesia 2015. PB PERKENI.

Powers, M. A., Bardsley, J., Cypress, M., Duker, P., Funnell, M. M., Hess Fischl, A., ... Vivian, E. (2015). Diabetes Self-management Education and Support in Type 2 Diabetes: A Joint Position Statement of the American DPowers, M. A., Bardsley, J., Cypress, M., Duker, P., Funnell, M. M., Hess Fischl, A., ... Vivian, E. (2015). Diabetes Self-management Education an. Diabetes Care, 38(7), 1372-1382. https://doi.org/10.2337/dc15-0730

Pradilasari, L., Gani, A., \& Khaldun, I. (2019). Pengembangan Media Pembelajaran Berbasis Audio Visual pada Materi Koloid Untuk Meningkatkan Motivasi dan Hasil Belajar Siswa SMA. Jurnal Pendidikan Sains Indonesia, 07(01), 9-15. https://doi.org/10.24815/jpsi.v7i1.13293

Prasetiyo, N. A., \& Perwiraningtyas, P. (2017). Pengembangan buku ajar berbasis lingkungan hidup pada matakuliah biologi di universitas tribhuwana tunggadewi. Jurnal PPndidikan Biologi Indonesia, 3(1), 19-27.

RISKESDAS. (2018). Hasil Utama Riset Kesehatan Dasar 2018. Kementrian Kesehatan Republik Indonesia, 1-100. https://doi.org/1 Desember 2013

Rosymida, I., Adi, H., \& Aisah, S. (2018). Gambaran Pendidikan Kesehatan yang Dilakukan Perawat Di Poliklinik RSUP Dr. Kariadi Semarang.

Sanjaya, W. (2011). Perencanaan dan Desain Sistem Pembelajaran (cetakan 4). Jakarta: Kencana.

Supriyadi. (2019). Pemanfaatan Plugin After Effect Untuk Produksi Film. Jurnal Komunikasi, $10(1)$ $1-3$. 
